\title{
Первый успешный опыт создания резервной колонии крапчатого суслика (Spermophilus suslicus (Güldenstädt, 1770)) и благоприятствующие этому условия
}

\author{
С.Ф. Сапельников ${ }^{1}$, И.И. Сапельникова ${ }^{2}$ \\ ${ }^{1}$ Ломовской природный ландшафтный парк, \\ Россия, 397570, Воронежская обл., Воробьёвский р-н, с. Воробьёвка, пл. Свободы, 2 \\ ${ }^{2}$ Воронежский государственный природный биосферный заповедник им. В.М. Пескова, \\ Россия, 394080, г. Воронеж, Госзаповедник \\ E-mail: sapelnikov@reserve.vrn.ru; is@ reserve.vrn.ru
}

\begin{abstract}
Аннотация. Численность крапчатого суслика (Spermophilus suslicus (Güldenstädt, 1770)) катастрофически сократилась по всему ареалу. Известные попытки сохранения вида до сих пор были неуспешны. Целью работы явилось создание резервной колонии крапчатого суслика путем реинтродукции зверьков в рекреационной зоне. Поселение крапчатого суслика создано в Воробьёвском районе Воронежской области (Россия) на территории Ломовского природного парка. Выбору места для реинтродукции сусликов способствовал комплекс необходимых для этой цели условий. Всего за лето 2020 г. и раннюю весну 2021 г. с сохранившейся на кладбище под Липецком популяции было завезено и выпущено 214 особей. К июлю 2021 г. суслики размножились и расселились на площади более 7 га. Численность новой колонии составила ориентировочно около 300 особей. Впервые за семь лет реинтродукционных работ получена устойчивая вольная колония вида. Исходя из полученного опыта, предлагается в дальнейшем для создания резервных популяций крапчатого суслика использовать рекреационные зоны, схожие по условиям с Ломовским парком.
\end{abstract}

Ключевые слова: крапчатый суслик, Spermophilus suslicus, реинтродукция, рекреационная зона, редкие виды, синантропный вид.

Для цитирования: Сапельников С.Ф., Сапельникова И.И. 2021. Первый успешный опыт создания резервной колонии крапчатого суслика (Spermophilus suslicus (Güldenstädt, 1770)) и благоприятствующие этому условия. Полевой журнал биолога, 3 (3): $284-297$. DOI: $10.52575 / 2658-3453-2021-3-3-284-297$

\section{The First Successful Experience of Creating a Reserve Colony of Spermophilus suslicus (Güldenstädt, 1770) and Favorable Conditions for It}

\author{
Sergey F. Sapelnikov ${ }^{1}$, Inna I. Sapelnikova ${ }^{2}$ \\ ${ }^{1}$ Lomovskoy Natural Landscape Park, \\ 2 Svobody Sq, Vorobievka vill., Vorobievskiy District, Voronezh Region, 397570, Russia \\ ${ }^{2}$ Voronezh State Natural Biosphere Reserve named after V.M. Peskov, \\ Goszapovednik, Voronezh, 394080, Russia \\ E-mail: sapelnikov@ reserve.vrn.ru; is@ reserve.vrn.ru
}

\begin{abstract}
The number of speckled ground squirrel (Spermophilus suslicus (Guldenstädt, 1770)) has dramatically decreased in the entire range. Well-known attempts to preserve the species both in protected areas and in an optimal natural habitat have so far been unsuccessful. Isolated colonies have been preserved in the habitats that have been changed and are now used by humans. The aim of the work was
\end{abstract}


to create a reserve colony of speckled ground squirrel by reintroducing the animals in the recreational area. The settlement of the speckled ground squirrel was created in the Vorob yovskij district of the Voronezh Region (Russia) on the territory of the Lomovskoj Natural Park. The choice of a place for the reintroduction of ground squirrels was facilitated by a set of conditions necessary for this purpose. In total, during the summer of 2020 and early spring of 2021, 214 individuals were imported and released from the population preserved at the cemetery near Lipetsk. By July 2021, ground squirrels had multiplied and settled on an area of more than 7 hectares. At the same time, the number of the new colony was approximately about 300 osobey. For the first time in seven years of reintroduction work, a stable free colony of the species was obtained. The success of the project was facilitated by the desire of the director and staff of the park to restore the native species population on its territory, as well as the tolerant attitude of the small animals to people nearby. Based on the experience gained, it is proposed to use recreational zones similar in terms of conditions to the Lomovskoj Park in the future to create reserve populations of speckled ground squirrel.

Keywords: speckled ground squirrel, Spermophilus suslicus, reintroduction, recreational area, rare species, synanthropic species.

For citation: Sapelnikov S.F., Sapelnikova I.I. 2021. The First Successful Experience of Creating a Reserve Colony of Spermophilus suslicus (Güldenstädt, 1770) and Favorable Conditions for It. Field Biologist Journal, 3 (3): 284-297 (in Russian). DOI: 10.52575/2658-3453-2021-3-3-284-297

Received August 25, 2021

\section{Введение}

Крапчатый суслик (Spermophilus suslicus (Güldenstädt, 1770)) занесен во второе издание Красной книги РФ ${ }^{1}$ сразу с категорией 2, поскольку в последнее время катастрофически сократилась его численность по всему ареалу, что требует безотлагательного принятия мер по спасению популяций. Однако попытки сохранения вида на заповедных территориях в итоге закончились его постепенным исчезновением [Брандлер и др., 2012; Недосекин, 2014, 2016], а в условиях зоопарков крапчатый суслик пока не размножается и даже не представлен в коллекция ${ }^{2}$. Также не смогли устойчиво существовать колонии, созданные в оптимальной естественной среде обитания, основной причиной чего явились многочисленные дикие и домашние хищники [Сапельников, 2019; Сапельников, Сапельникова, 2020а].

В то же время зафиксированы факты многолетнего существования популяций крапчатого суслика на антропогенно трансформированных территориях [Сапельников и др., 2007а, 2007б; Пиванова, Шубина, 2010а, 2010б, 2010в; Калмацкий, 2016; Ситникова, 2016; Проявка и др., 2017]. Ретроспективный анализ состояния популяций вида на обширной части ареала также показал, что от бывшей ранее сплошной природной популяции сохранились лишь единичные колонии, приспособленные, как правило, к измененным и ныне используемым человеком местообитаниям. В этой связи предлагается рассматривать крапчатого суслика не как «дикий», а как синантропный вид, способный выжить в современных условиях только под защитой человека, в местах массового посещения людьми природных и иных объектов [Сапельников, Сапельникова, 2021].

1 Приказ Министерства природных ресурсов и экологии Российской Федерации от 24.03.2020 № 162 «Об утверждении Перечня объектов животного мира, занесенных в Красную книгу Российской Федерации». URL: http: docs.cntd.rudocument564578614 (дата обращения 17 ноября 2020).

${ }^{2}$ Информационный сборник, № 24-39. EAPA3A: URL: http:earaza.ru?page_id=31 (дата обращения 8 декабря 2020). 
Целью работы явилось создание резервной колонии крапчатого суслика (Spermophilus suslicus (Güldenstädt, 1770)) путем реинтродукции зверьков в рекреационной зоне.

\section{Объекты и методы исследования}

Подходящим участком для выпуска сусликов «под ноги» человеку оказалась территория Ломовского природного ландшафтного парка в Воробьёвском районе Воронежской области, расположенного у границы с Волгоградской областью. При этом колониейдонором послужила единственная крупная в Черноземье популяция, чудом сохранившаяся в 240 км севернее Ломовского парка на антропогенно трансформированной территории под Липецком [Пиванова, Шубина, 2010а] (рис. 1). Ломовской природно-ландшафтный парк расположен среди полей на месте бывшего степного хутора Ломы у заполненного заново пруда с восстановленной плотиной (рис. 2). Нахождение территории парка вдали от поселений человека (до ближайшего хутора Высокого - не менее 2 км по прямой) максимально исключает присутствие здесь собак и кошек, особенно опасных для сусликов. Это явилось одним из основных условий при выборе места для новой колонии.

Вторым не менее важным обстоятельством явилось вхождение территории парка в исторический ареал крапчатого суслика [Zagorodnyuk et al., 2008] (рис. 3).

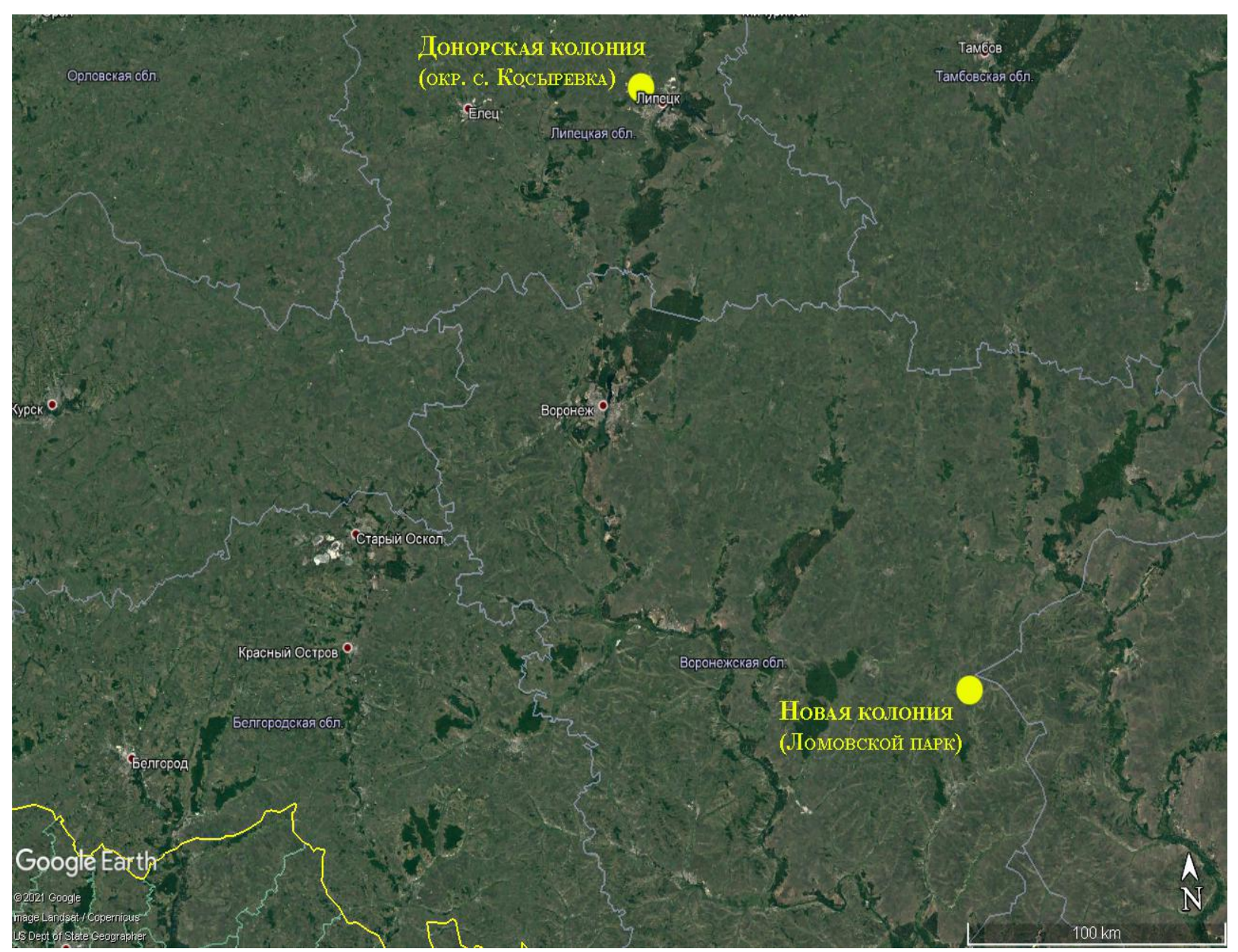

Рис. 1. Донорская и реинтродуцированная (новая) колонии крапчатого суслика на территории Центрального Черноземья

Fig. 1. Donor and reintroduced (new) colonies of speckled ground squirrel in Central Black Earth Region 


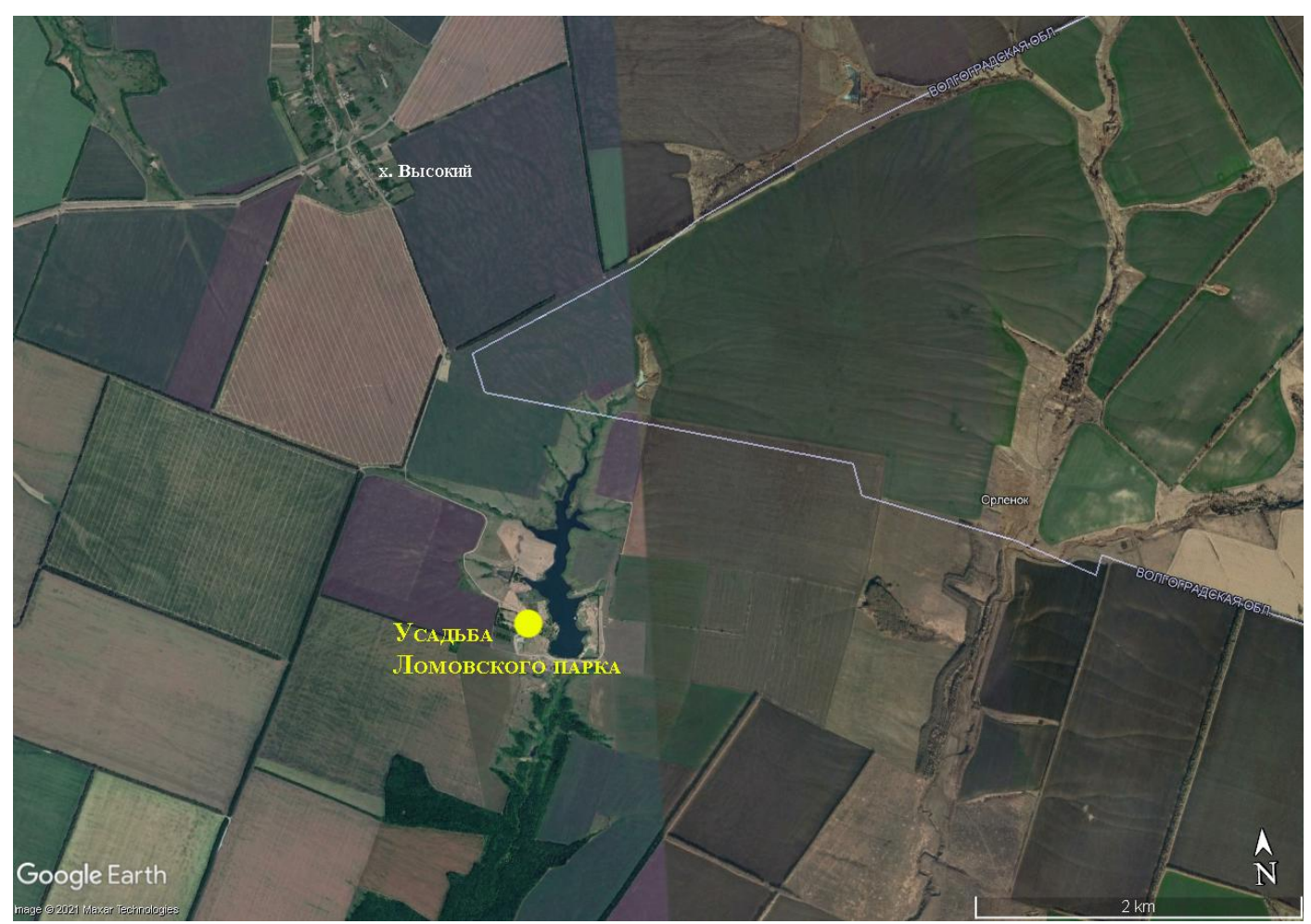

Рис. 2. Расположение Ломовского парка на местности

(Воронежская область, Воробьёвский район), вдали от людских поселений

Fig. 2. The location of Lomovskoj Park in the area

(Voronezh Region, Vorobievsky District), far from human settlements

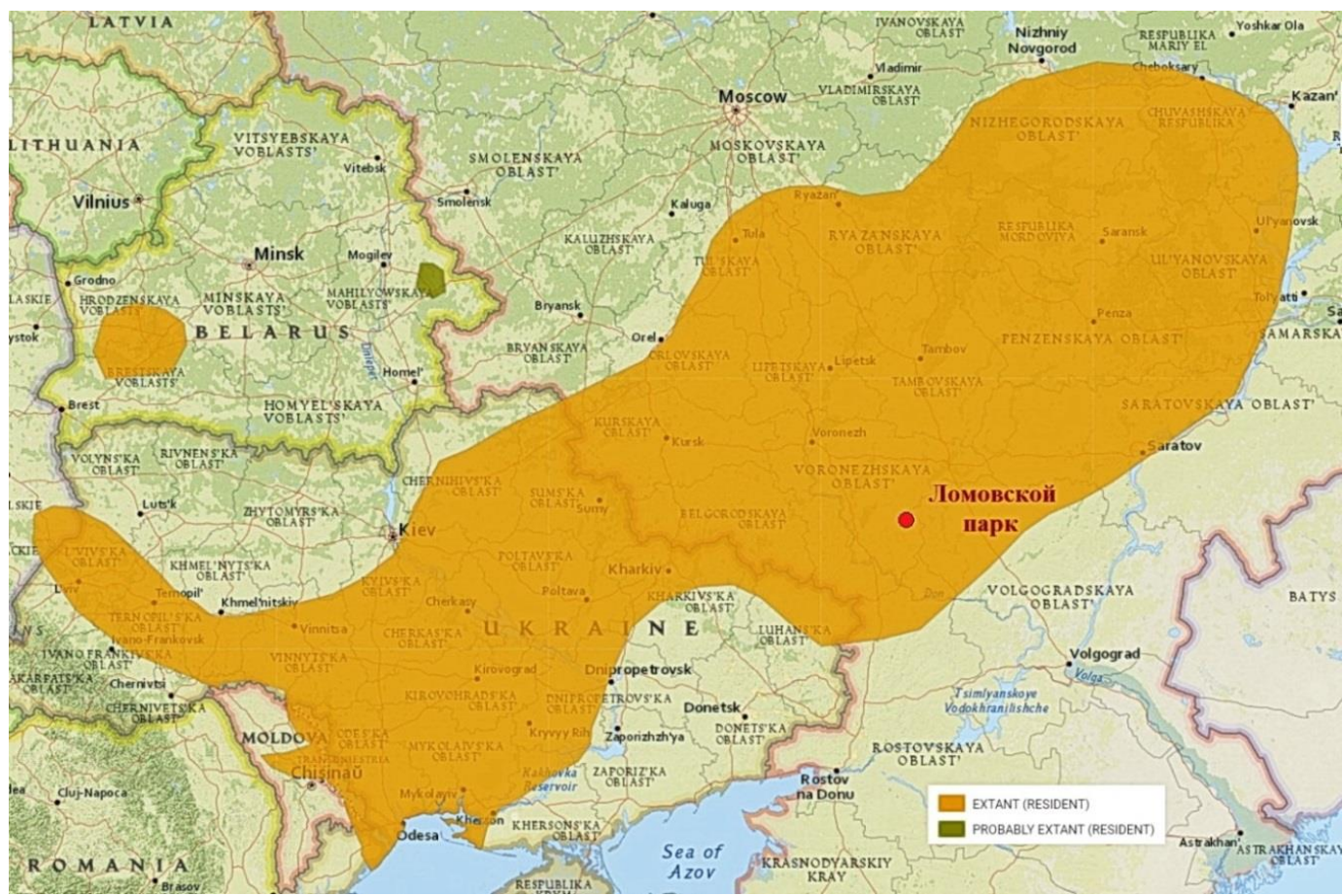

Рис. 3. Ареал крапчатого суслика [Zagorodnyuk et al., 2008]

и место успешной реинтродукции вида - Ломовской парк (Воронежская обл., Воробьёвский район) Fig. 3. Area of speckled ground squirrel [Zagorodnyuk et al., 2008] and place of successful reintroduction of species - Lomovskoj Park (Voronezh Region, Vorobievsky District) 
В этих местах плотность населения вида по средним показателям за 1951-1954 гг. считалась относительно высокой (свыше 50 жилых нор на 1 га при средней годовой добыче свыше 400 зверьков на 1000 га) [Барабаш-Никифоров, 1957], что свидетельствует об исторически оптимальных условиях для вида и хороших предпосылках для его реинтродукции.

Отлов и выпуск сусликов проводили в 2020 и 2021 гг. в целом по отработанной ранее методике [Сапельников, Сапельникова, 2020б]. При этом весной 2021 г. в методику были введены некоторые существенные дополнения. При подселении в колонию новых партий зверьков их выпускали теперь не в новые, свеженабуренные норки, а в обжитые, к уже имеющимся там хозяевам. По нашим наблюдениям, в многолетней донорской колонии суслики при опасности нередко заскакивали в чужие норы, о чём свидетельствовало недовольное стрекотание зверьков, доносящееся из нор. Однако такие конфликты с хозяевами обычно вскоре утихали, не нанося зверькам, по всем признакам, ощутимого вреда. На практике выпуск сусликов в жилые норы показал успешность и перспективность такого метода. По всей видимости, при конфликте на новом месте с особями своего вида на фоне сформированного сигнального поля зверьки испытывают гораздо меньший стресс, чем от попадания в свежие, необжитые норы, из которых стараются сразу убежать подальше. Покидая же нору хозяина в центре колонии, зверьки ведут себя более уверенно и быстрее находят для себя подходящие норы поблизости.

\section{Результаты и их обсуждение}

Всего за июнь - июль 2020 г. и апрель 2021 г. на усадьбе Ломовского парка было выпущено 214 сусликов - 118 самцов и 96 самок (см. таблицу).

Половозрастной состав крапчатого суслика при реинтродукции в Ломовском парке

(Воронежская область, Воробьёвский район) в 2020-2021 гг.

Age and sex composition of speckled ground squirrel during reintroduction in Lomovskoj Park (Voronezh Region, Vorobievsky District) in 2020-2021

\begin{tabular}{|c|c|c|c|c|c|c|c|c|}
\hline \multirow{2}{*}{$\begin{array}{c}\text { Дата } \\
\text { выпуска }\end{array}$} & \multirow{2}{*}{$\begin{array}{c}\text { Весто } \\
\text { выпуска }\end{array}$} & \multicolumn{3}{|c|}{ Самцы } & \multicolumn{3}{|c|}{ Самки } & \multirow{2}{*}{ Итого } \\
\cline { 3 - 8 } & взрослые & молодые & всего & взрослые & молодые & всего & \\
\hline 29.06 .2020 & I & 21 & 10 & 31 & 21 & 8 & 29 & 60 \\
\hline 12.07 .2020 & II & 14 & 8 & 22 & 8 & 5 & 13 & 35 \\
\hline 19.07 .2020 & II & 9 & 3 & 12 & 4 & - & 4 & 16 \\
\hline 11.04 .2021 & I & 9 & - & 9 & 2 & - & 2 & 11 \\
\hline 14.04 .2021 & I & 15 & - & 15 & 5 & - & 5 & 20 \\
\hline 20.04 .2021 & I & 9 & - & 9 & 11 & - & 11 & 20 \\
\hline 27.04 .2021 & II & 8 & - & 8 & 13 & - & 13 & 21 \\
\hline 30.04 .2021 & II & 12 & - & 12 & 19 & - & 19 & 31 \\
\hline 2020 & I и II & 44 & 21 & 65 & 33 & 13 & 46 & 111 \\
\hline 2021 & I и II & 53 & - & 53 & 50 & - & 50 & 103 \\
\hline Всего & I и II & 97 & 21 & 118 & 83 & 13 & 96 & 214 \\
\hline
\end{tabular}

Примечание: участки выпуска зверьков на территории Ломовского парка: I - на холме у соломенной беседки в районе пляжа; II - вдоль каменной кладки вблизи здания комплекса (рис. 4).

Note: areas for release of animals on territory of Lomovskoj Park: I - on a hill near a thatched arbor near the beach; II - along the masonry near the building of the complex (Fig. 4). 


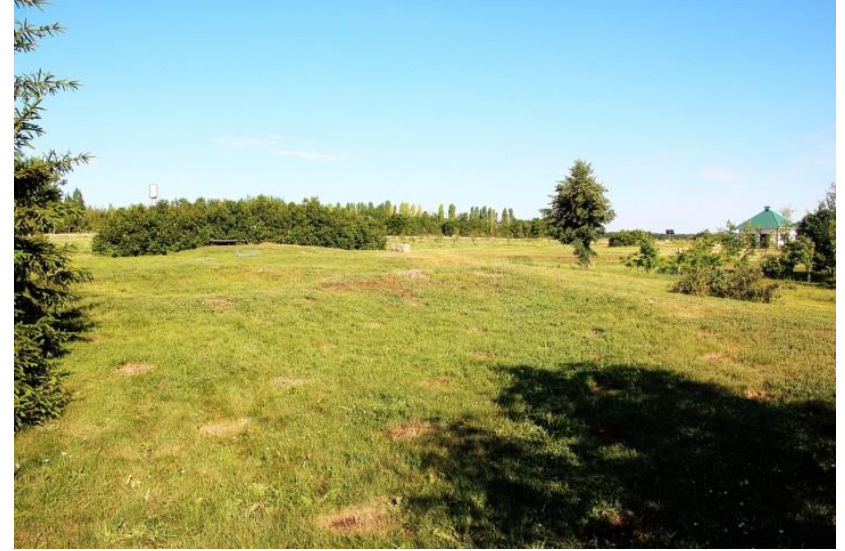

I

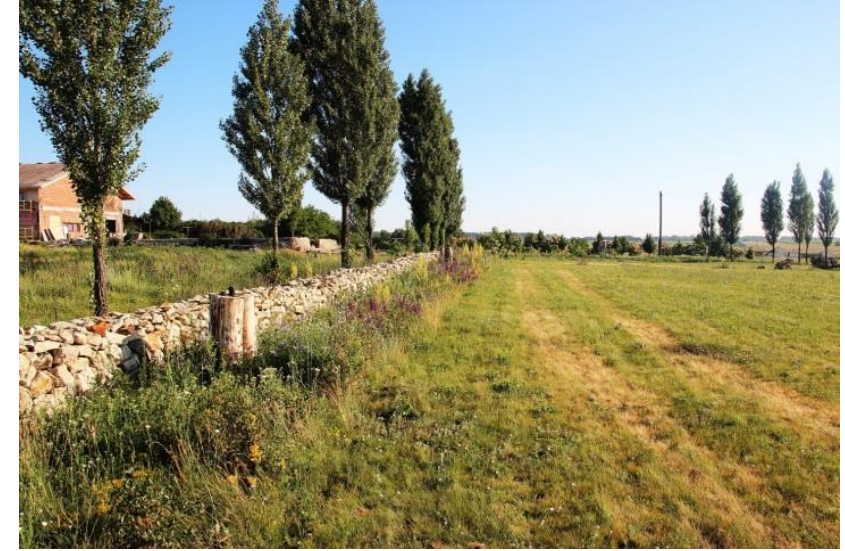

II

Рис. 4. Места выпуска сусликов на территории Ломовского парка

(Воронежская область, Воробьёвский район) в 2020-2021 гг.:

I - холм от бывшего дома у еловой аллеи; II - участок вдоль каменной кладки у офиса парка

Fig. 4. Places of release of ground squirrels on territory of Lomovskoy Park

(Voronezh Region, Vorobievsky District) in 2020-2021:

I - a hill from former house near spruce alley; II - section along stone masonry near park office

При этом доля сеголетков в новой колонии 2020 г. составила 30,6 \%, что обеспечивает необходимый репродуктивный потенциал. Весной 2021 г. для подселения в новую колонию отловили 103 перезимовавших особи из донорской группировки, почти поровну самцов и самок. Отлов проводили до конца апреля и закончили с первым появлением в уловах самок с эмбрионами размером чуть больше горошины. На этой стадии беременности у самок остается достаточный запас времени, чтобы прижиться на новом месте, выбрать подходящую нору и подготовить гнездо к рождению суслят. Летом 2021 г. подселений не проводили по причине отсутствия в этом необходимости. Выпуск сусликов в парке проводили на двух участках - на холме у соломенной беседки в районе пляжа (I) и вдоль каменной кладки вблизи здания комплекса (II) (см. рис. 4).

Новая колония в течение года хорошо освоилась, размножилась и расселилась по территории, заняв площадь в 7,4 га (определена по крайним норам). Количество нор, вырытых самими зверьками, достигло на начало июля 616, из которых 176 оказались вертикальными и 440 - наклонными, что наглядно свидетельствует об интенсивной роющей деятельности расселяющихся зверьков. Численность новой колонии в этом случае может ориентировочно составлять около 300 особей (рис. 5).

Ломовской парк был создан в 2003 г. по инициативе начальника отдела культуры администрации Воробьёвского района и будущего директора парка В.В. Козлова как объект познавательного туризма и место отдыха. В процессе его развития наиболее освоенной оказалась территория на западном берегу пруда. Здесь оборудована грунтовая стоянка автомобилей, пляж, раздевалки, туалеты, летние домики для гостей и комфортабельные гостиничные номера. Посетители передвигаются по тропинкам, выложенным плиткой из природного камня. Вдоль склона юго-западной части берега сооружена на сваях монолитная бетонная тропа, слегка заглубленная в землю одной стороной по всей ее длине. По южной стороне пруда проложена деревянная настильная тропа, соединяющая западный и восточный берега. Для озеленения территории по берегу высажены ивы, чуть поодаль - березы, ели, пирамидальные тополя, различные кустарники. У холмов, оставшихся от бывших домов, сохранены кусты сирени. Посажен молодой яблоневый сад, который уже начал плодоносить. 


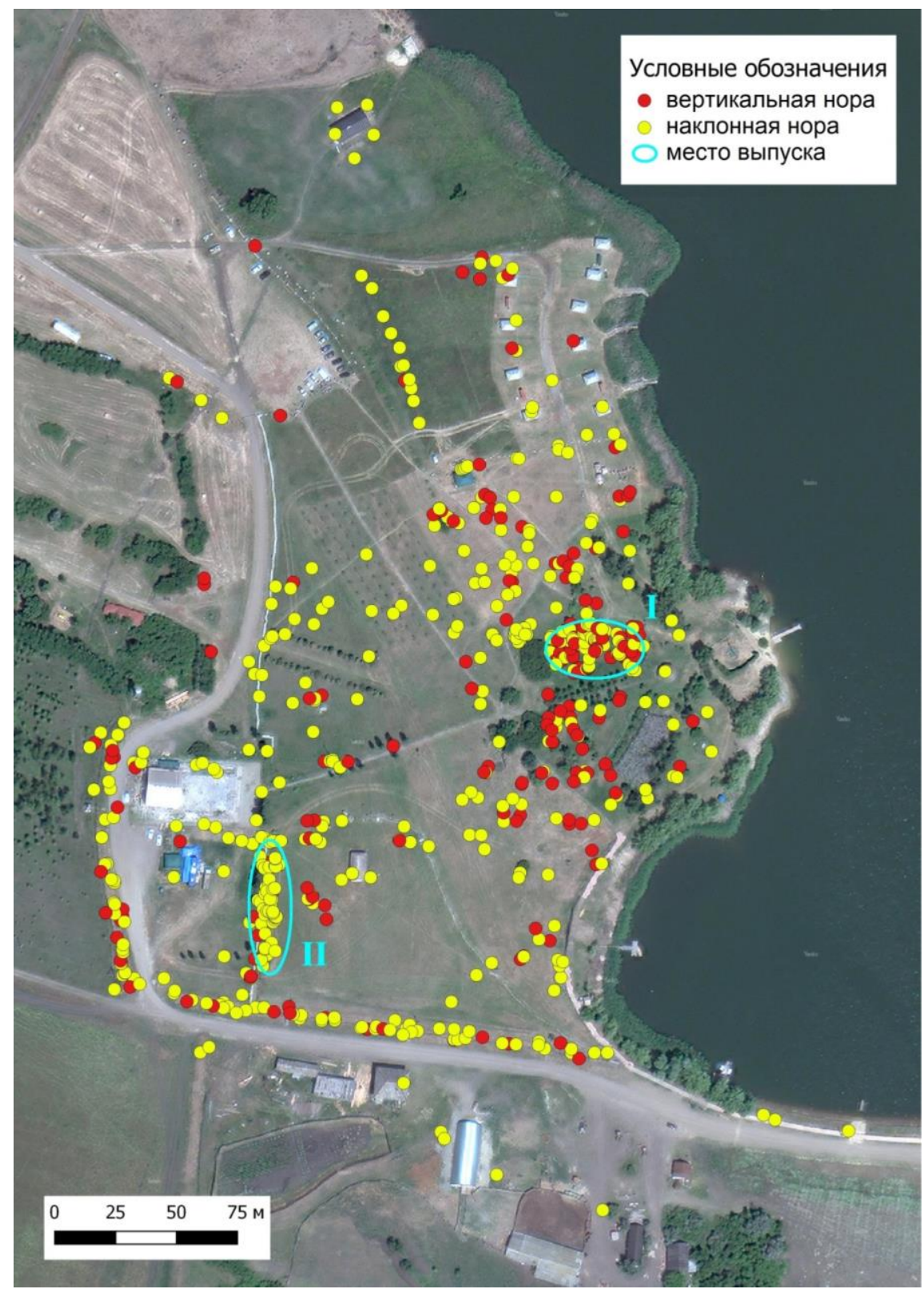

Рис. 5. Распределение нор крапчатого суслика на территории усадьбы Ломовского парка (по состоянию на 05.07.2021)

Fig. 5. Placement of speckled ground squirrel burrows on territory of Lomovskoj Park estate (as of 05.07.2021)

Для наглядного ознакомления экскурсантов с основами петрологии на территории парка собраны образцы горных пород в виде камней разной величины (рис. 6).

Почвы на территории парка представляют собой черноземы обыкновенные [Ахтырцев, 1994]. Для защиты их от весеннего и ливневого размывания вокруг пруда насыпаны высокие противоэрозионные валы, постепенно обрастающие густым травяным покровом. Они так же, как и большая часть территории усадьбы, обеспечены системой автоматического полива, при этом подрастающий травяной покров регулярно подстригается бензокосой или газонокосилкой на уровне около 10 см от земли. Такое кошение препятствует распространению крупностебельной сорной растительности и способствует сохранению участков открытых лугово-степных стаций, приближенных к пастбищным условиям (рис. 7). 


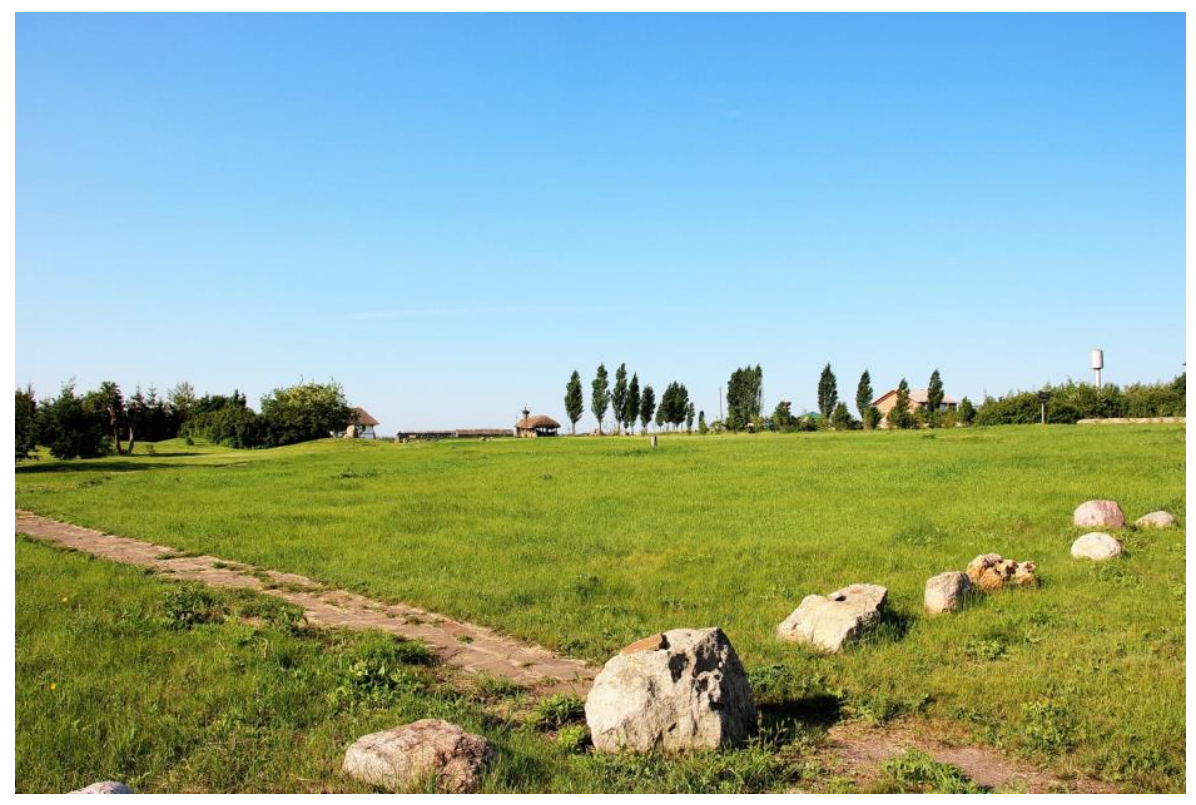

Рис. 6. Северная часть усадьбы парка с разложенными по территории камнями

Fig. 6 . The northern part of the park estate with stones spread over the territory
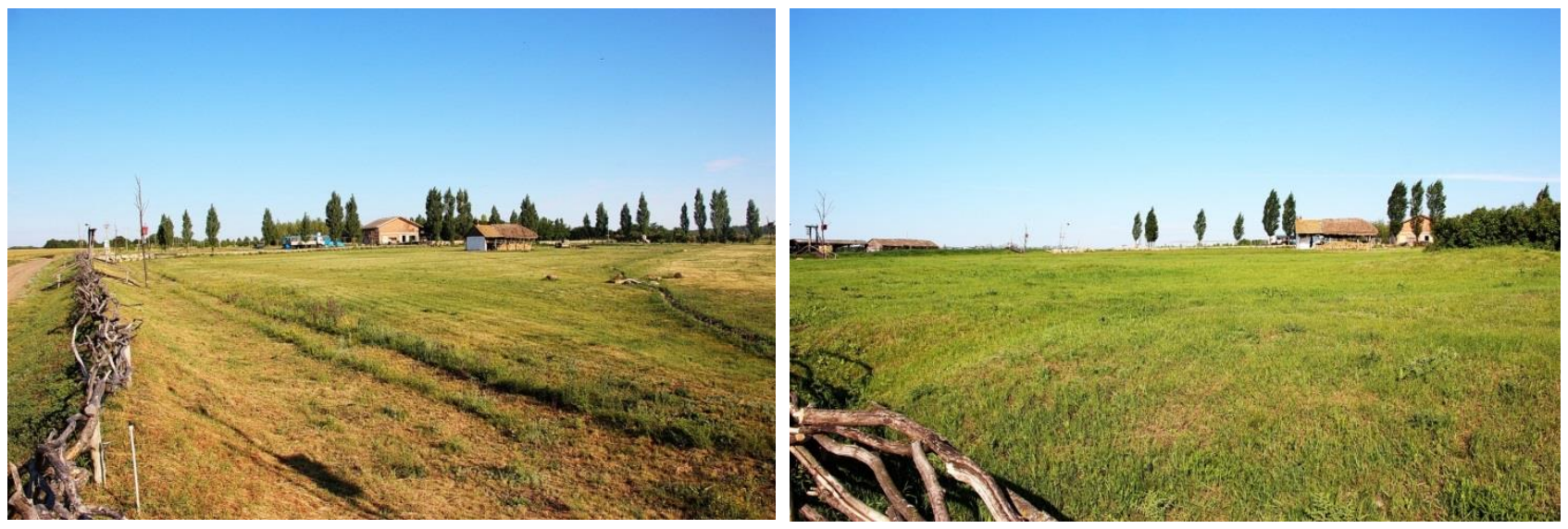

Рис. 7. Участки парка: южный, с противоэрозионным валом (слева), и центральный (вал вдали)

Fig. 7. Sites of the park: southern, with an anti-erosion shaft (left), and central (shaft in the distance)

Все перечисленные результаты и действия по облагораживанию парка были, несомненно, направлены в первую очередь на создание привлекательных условий для его посетителей. Однако на практике оказалось, что эти же условия наилучшим образом подходят для обитания сусликов.

Регулярный тримминг открытых степных участков обеспечивает требующуюся для вида возможность широкого обзора и визуальной коммуникации. Ночной полив естественных газонов обеспечивает полноценное питание зелеными побегами и продлевает период нажировки. По мере созревания яблок зверьки из окрестных нор постепенно переселяются в сад, где питаются падалицей плодов.

Крупные камни на усадьбе привлекают вначале сусликов как хорошо заметные укрытия, в дальнейшем провоцируя их на рытье здесь нор (рис. 8). Нередко у таких камней возникают потасовки из двух-трех зверьков, отстаивающих своё право на них. 


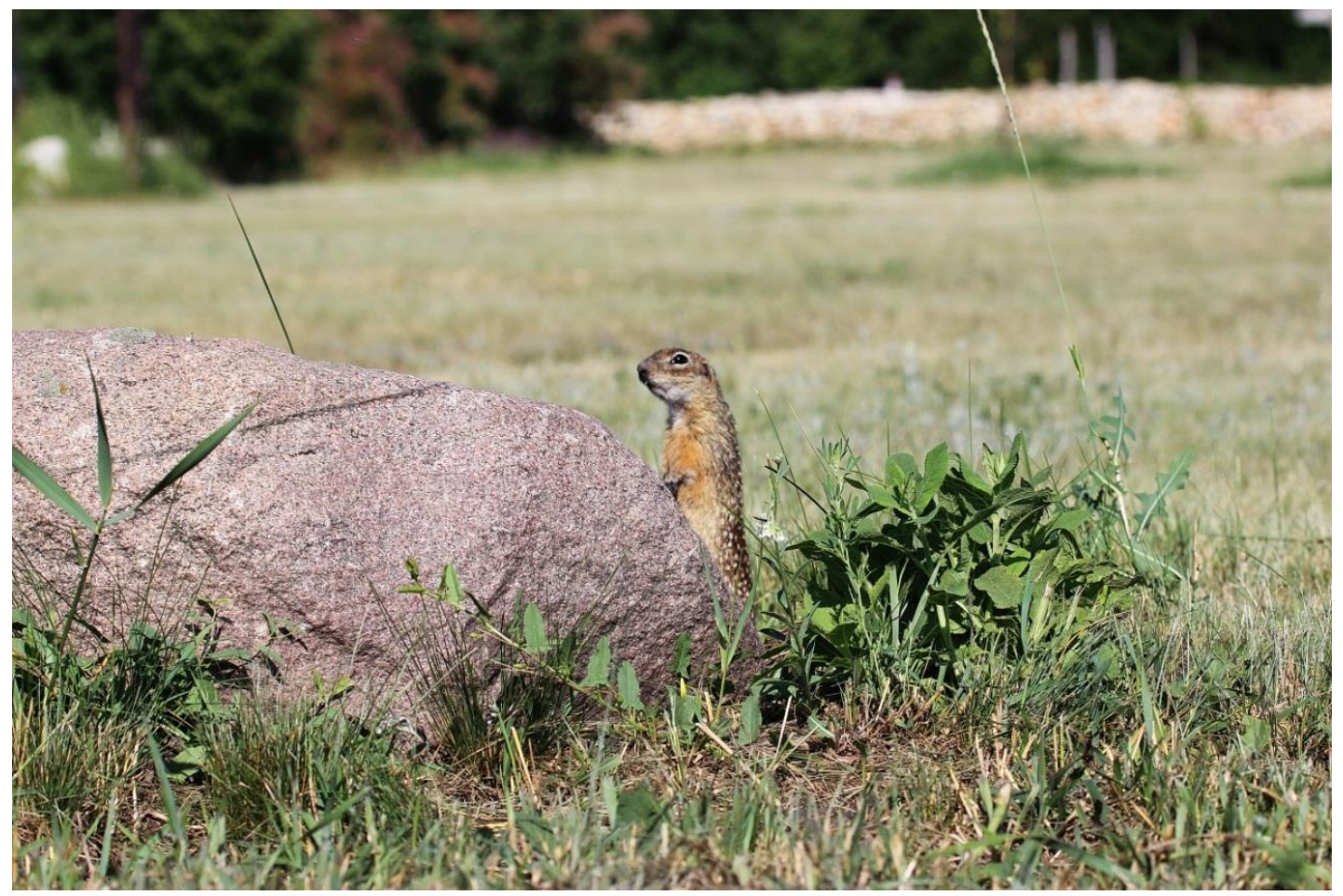

Рис. 8. Суслик на сторожевом посту у своей наклонной норы под камнем

Fig. 8. A speckled ground squirrel at a guard post at its inclined burrow under a stone

Различные наземные постройки и сооружения, создаваемые для людей, в первую очередь стоящие отдельно, также быстро осваиваются зверьками (рис. 9, 10).

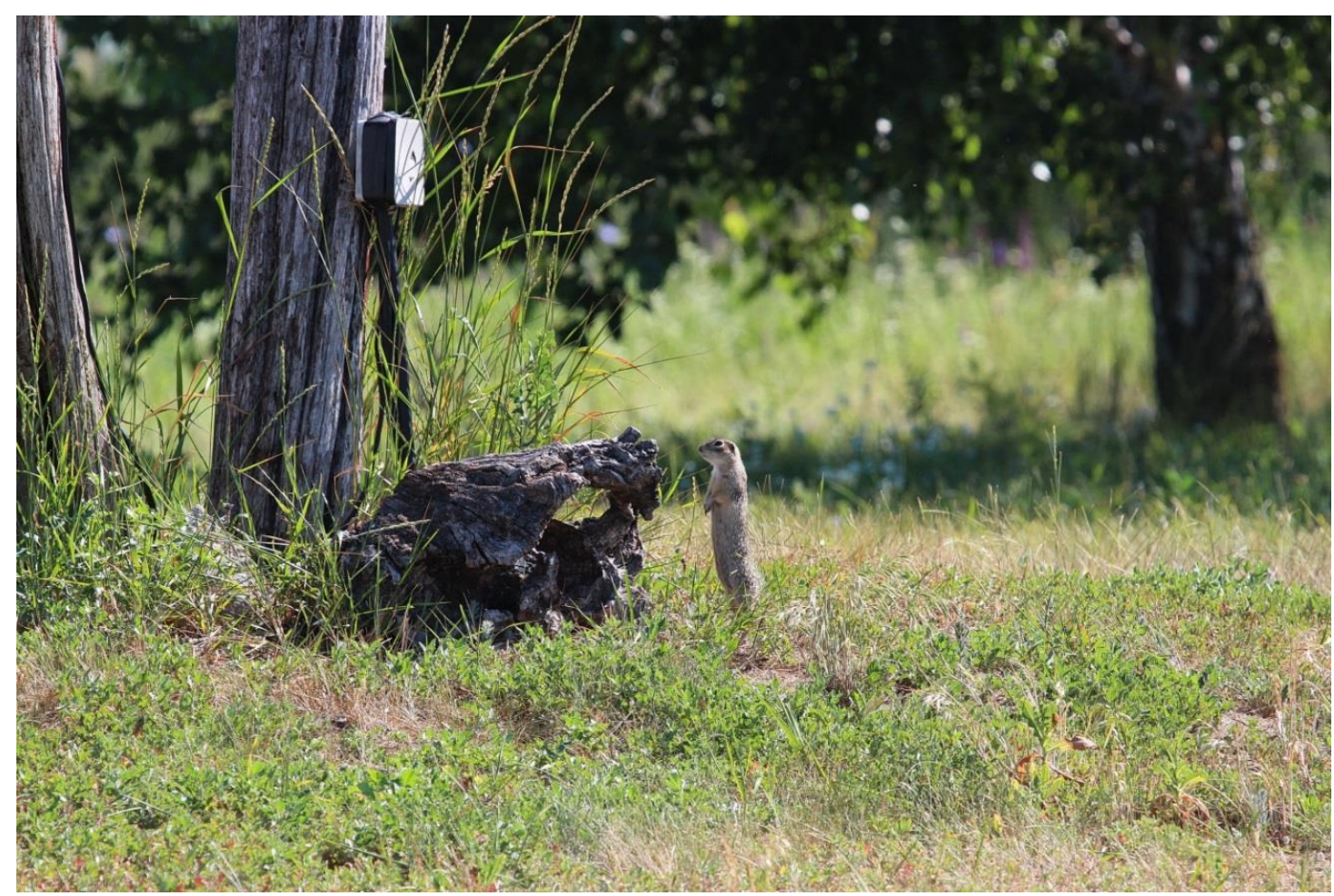

Рис. 9. Суслик у норы под декоративным уличным светильником

Fig. 9. Speckled ground squirrel at the hole under a decorative street lamp 


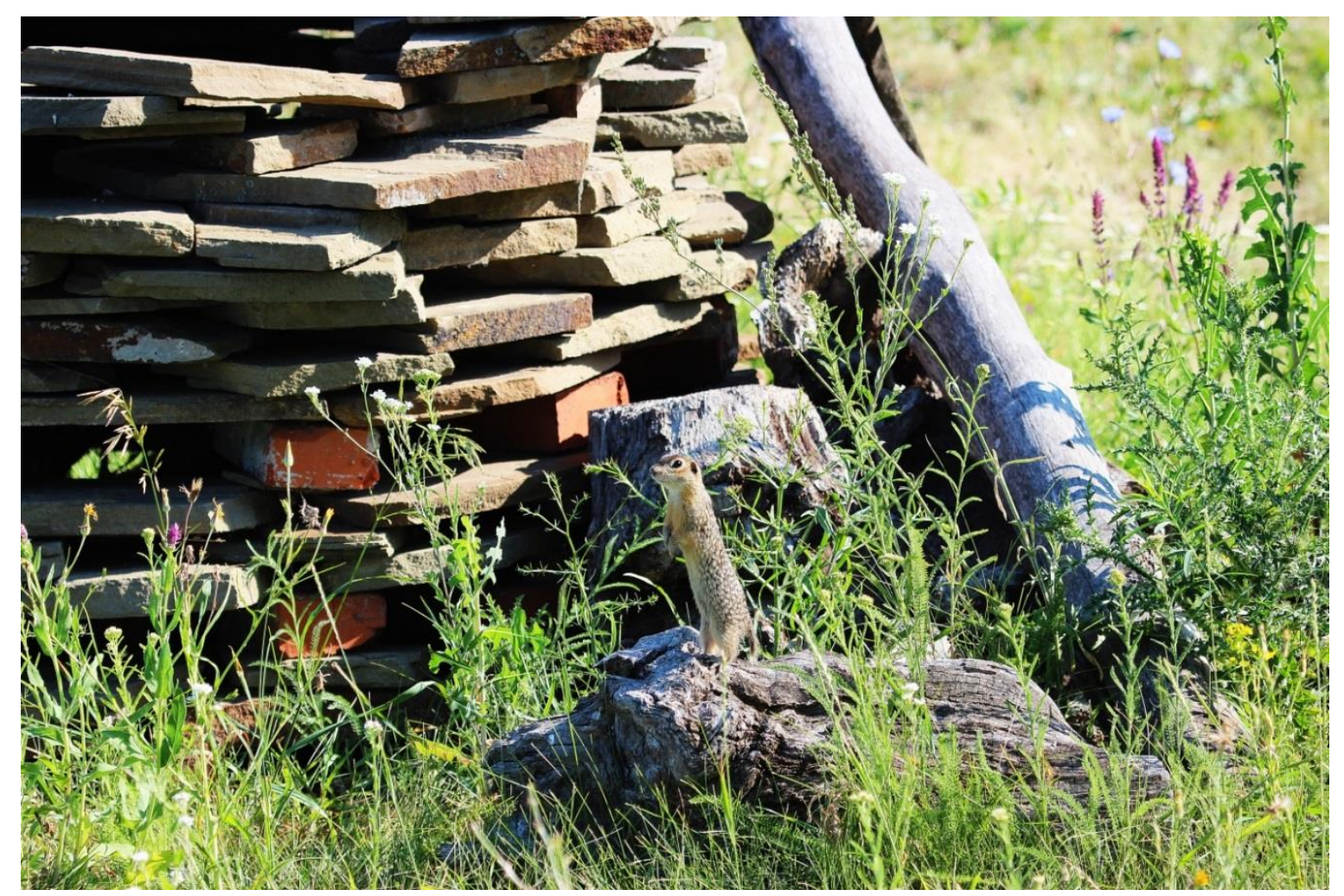

Рис. 10. Суслик выбрал место для норы у декоративной кладки и старых пней

Fig. 10. The speckled ground squirrel chose a place for a burrow near decorative masonry and old stumps

Особенно привлекательны для сусликов противоэрозионные валы (см. рис. 7), которые осваиваются зверьками, как правило, по всей их длине и служат как бы барьером при расселении сусликов с мест выпуска (см. рис. 5). Холмы, оставшиеся от бывших домов, состоят обычно из легких сухих почв с примесью пепла, в которых особенно успешно проходит зимовка зверьков.

Посетители парка невольно выступают в роли защитного фактора для сусликов, так как уже своим присутствием на территории парка отпугивают большинство диких хищников, в первую очередь лисиц. Суслики же относительно быстро привыкают к нахождению вблизи людей, их передвижениям и проявлению к зверькам интереса (фото- и видеосъемка). При их слишком близком подходе суслики прячутся в норки, люди, не видя зверьков, уходят, суслики после этого выходят и продолжают кормиться.

Наибольшую опасность в условиях Ломовского парка, как и во всем Центральном Черноземье, представляет для сусликов орел-карлик (Hieraaetus pennatus (Gmelin, 1788)) [Сапельников, 2019; Сапельников, Сапельникова, 2020а] (рис. 11). Этот орел может успешно охотиться на многие виды животных, но при обнаружении им колонии сусликов быстро переключается на этот вид. Не сильно опасаясь людей, в день пара орлов уносит от одного до четырёх и более зверьков, нередко пикируя на них со стороны солнца. Частично воспрепятствовать этому в условиях парка помогает защитный проволочный экран, подвешенный на высоте 2,5-3 м над маточной частью колонии (рис. 12). Проволока, натянутая с интервалом 0,5-0,8 м, максимально препятствует свободному пикированию орлов на сусликов, что, безусловно, спасает зверькам жизни. В планах парка - увеличение площади защитного проволочного экрана. 


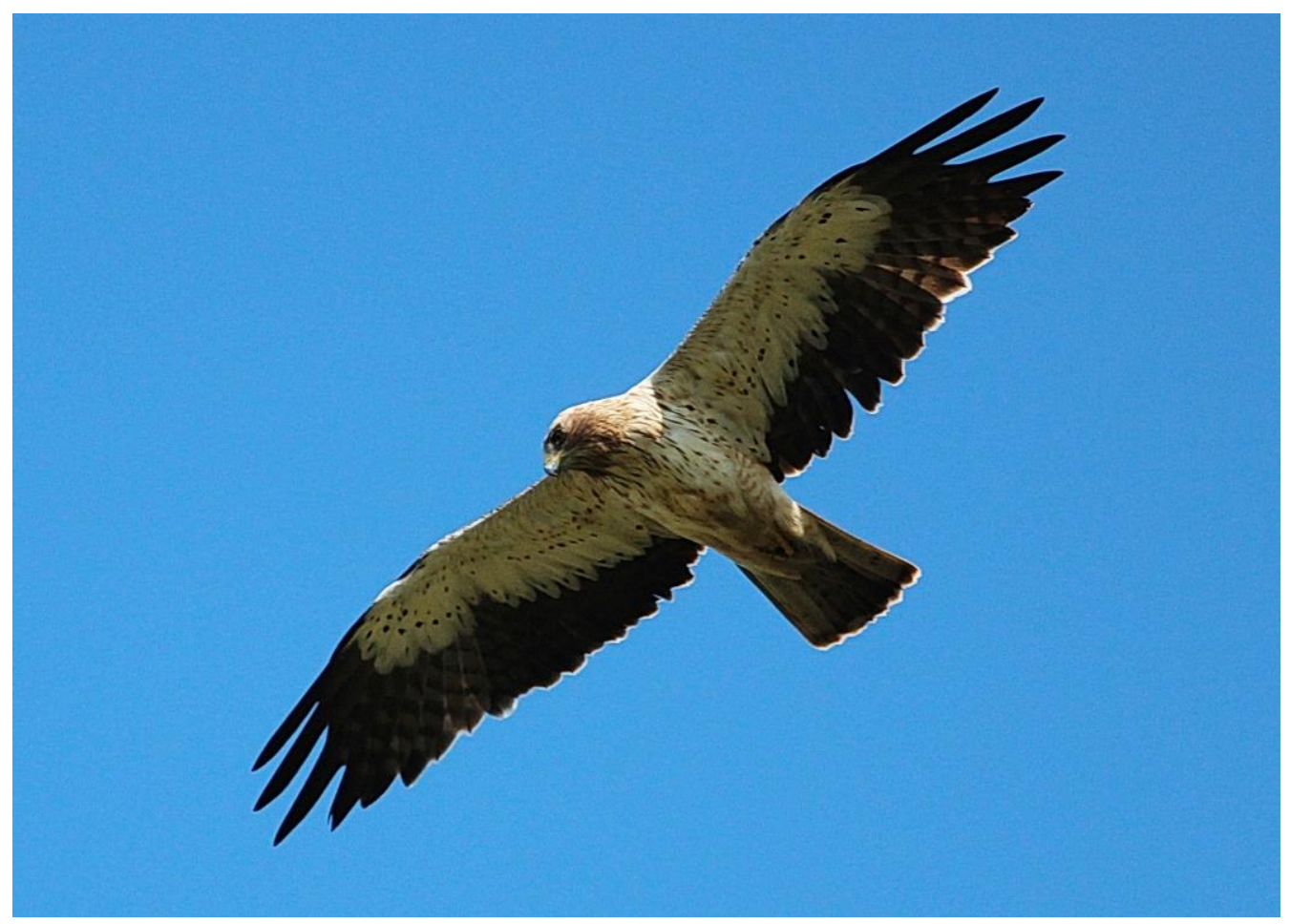

Рис. 11. Орёл-карлик светлой морфы, высматривающий добычу Fig. 11. A dwarf eagle of light morph, looking out for prey

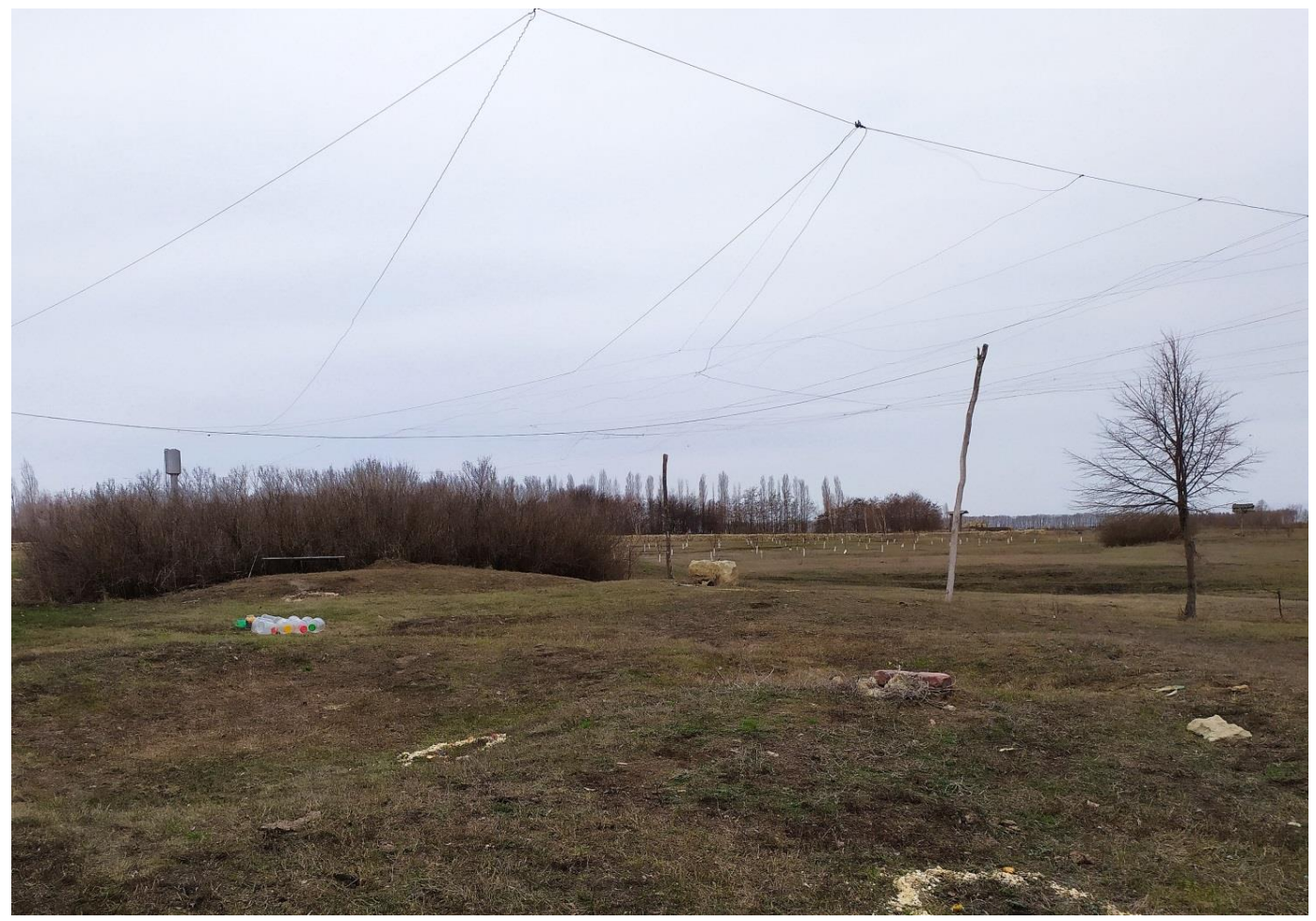

Рис. 12. Защитный экран из проволоки над маточной частью колонии на участке I (слева - цветные емкости для перевозки сусликов)

Fig. 12. Protective screen made of wire above the mother part of the colony at site I (on the left - colored containers for transportation of ground squirrels) 


\section{Заключение}

Успеху проекта во многом способствовало стремление директора и персонала парка к восстановлению на его территории популяции аборигенного вида, который в любой момент может навсегда исчезнуть из фауны Земли.

Исходя из полученного опыта, предлагается в дальнейшем для создания резервных популяций крапчатого суслика использовать зоны отдыха людей, схожие по условиям с Ломовским природным ландшафтным парком.

\section{Список литературы}

1. Ахтырцев А.Б. 1994. Почвы и почвенные ресурсы. В кн.: Атлас Воронежской области. Воронеж, Изд-во Воронежского университета: с. 20.

2. Барабаш-Никифоров И.И. 1957. Крапчатый суслик - Citellus suslica Güld. В кн.: Звери юго-восточной части Черноземного центра. Воронеж: 219-232.

3. Брандлер О.В., Власова О.П., Власов Е.А. 2012. Реинтродукция степного сурка в Центрально-Черноземном заповеднике. Степной бюллетень, 35: 50-55.

5. Калмацкий М. 2016. Кто свистит на НПС? Трубопроводный транспорт нефти, 9: 68-71. URL: https://www.transneft.ru/u/eco_publish_file/132/sysliki.pdf (дата обращения: 9 февраля 2021).

6. Недосекин В.Ю. 2014. Млекопитающие. B кн.: Природа Плющани. Воронеж, Издательство «Научная книга»: 243-253.

7. Недосекин В.Ю. 2016. Класс млекопитающие - Mammalia. В кн.: Позвоночные заповедника «Галичья гора». Воронеж, Издательский дом ВГУ: 144-165.

8. Пиванова С.В., Шубина Ю.Э. 2010а. Городское кладбище как место сохранения популяции крапчатого суслика. $B$ кн.: Видовые популяции и сообщества в антропогенно трансформированных ландшафтах: состояние и методы его диагностики. Материалы XI Международной научно-практической экологической конференции (Белгород, 20-25 сентября 2010 г.). Белгород, ИПЦ ПОЛИТЕРРА: 177-178.

9. Пиванова С.В., Шубина Ю.Э. 2010б. Размножение крапчатого суслика в пригородной зоне города Липецка. $B$ кн.: Первые Международные Беккеровские чтения (27-29 мая 2010 г.). Ч. 1. Волгоград: 495-496.

10. Пиванова С.В., Шубина Ю.Э. 2010в. Состояние популяции крапчатого суслика в природно-антропогенном ландшафте городского кладбища и его окрестностей. $B$ кн.: Проблемы изучения и восстановления ландшафтов лесостепной зоны. Сборник научных статей. Тула: 268-270.

12. Проявка С.В., Шубина Ю.Э., Савинецкая Л.Е., Шекарова О.Н. 2017. Морфологическая характеристика крапчатого суслика Spermophilus suslicus Центральной части европейской России. Известия высших учебных заведений. Поволжский регион. Естественные науки, 2 (18): 3-10.

13. Сапельников С.Ф. 2019. Почему не получилось создать новую колонию крапчатого суслика (Spermophilus suslicus). В кн.: Млекопитающие России: фаунистика и вопросы териогеографии. Материалы конференции (Ростов-на-Дону, 17-19 апреля 2019 г.). М., Тов-во научных изданий КМК: 247-250.

14. Сапельников С.Ф., Сапельникова И.И. 2020а. Результаты реакклиматизации крапчатого суслика на пастбище и возможные перспективы сохранения вида. $B$ кн.: Пространственновременные аспекты функционирования биосистем. Сборник материалов XVI Международной научной экологической конференции, посвящённой памяти Александра Владимировича Присного (Белгород, 24-26 ноября 2020 г.). Белгород, ИД «БелГУ» НИУ «БелГУ»: 112-117.

15. Сапельников С.Ф., Сапельникова И.И. 2020б. Опыт реинтродукции крапчатого суслика (Spermophilus suslicus Güld.) в природном парке «Олений». В кн.: Проблемы зоокультуры и экологии. Вып. 4. М., ГАУ «Московский зоопарк», ЕАРАЗА: 207-216.

16. Сапельников С.Ф., Сапельникова И.И. 2021. Ретроспективный анализ состояния популяций крапчатого суслика (Spermophilus suslicus Güldenstädt, 1770) в Центральном Черноземье с сопредельными территориями и возможные пути сохранения вида. Полевой журнал биолога, 3 (2): 167-212. DOI: 10.52575/2658-3453-2021-3-2-167-212.

17. Сапельников С.Ф., Соколов А.С., Лада Г.А., Скрылёва Л.Ф. 2007а. Придорожная колония крапчатого суслика на автотрассе Астрахань - Москва в Тамбовской области. $B$ кн.: 
Териофауна России и сопредельных территорий (VIII съезд Териологического общества). Материалы международного совещания. Москва, Т-во научных изданий КМК: 435.

18. Сапельников С.Ф., Соколов А.С., Лада Г.А., Скрылёва Л.Ф. 2007б. Экологоэтологические адаптации крапчатого суслика Spermophilus suslicus к современным условиям среды обитания. B кн.: Труды Воронежского государственного заповедника. Вып. 25. Воронеж: 279-285.

19. Ситникова Е.Ф. 2016. Крапчатый суслик - Spermophilus suslicus Guldenstaedt, 1770. В кн.: Красная книга Брянской области. 2-е издание. Брянск, РИО БГУ: 373.

20. Zagorodnyuk I., Glowacinski Z., Gondek A. 2008. Spermophilus suslicus. The IUCN Red List of Threatened Species 2008: e.T20492A9208074. http:dx.doi.org10.2305IUCN.UK.2008. RLTS.T20492A9208074.en.

\section{References}

1. Akhtyrtsev A.B. 1994. Pochvy i pochvennyye resursy [Soils and soil resources]. In: Atlas Voronezhskoy oblasti [Atlas of the Voronezh Region]. Voronezh, Voronezh State University Publishing House: p. 20.

2. Barabash-Nikiforov I.I. 1957. Krapchatyy suslik - Citellus suslica Güld [Speckled ground squirrel - Citellus suslica Güld]. In: Zveri yugo-vostochnoy chasti Chernozemnogo tsentra [Animals of the southeastern part of the Black Earth Center]. Voronezh: 219-232.

3. Brandler O.V., Vlasova O.P., Vlasov E.A. 2012. Reintroduktsiya stepnogo surka v Tsentral'noChernozemom zapovednike [Reintroduction of steppe marmot in the Central Black Earth Reserve]. Stepnoy byulleten', 35: 50-55.

5. Kalmatskiy M. 2016. Kto svistit na NPS? [Who whistles at the PS?]. Truboprovodnyy transport nefti, 9: 68-71. Available at: https://www.transneft.ru/u/eco_publish_file/132/sysliki.pdf (accessed February 9, 2021).

6. Nedosekin V.Yu. 2014. Mlekopitayushchie [Mammals]. In: Priroda Plyushchani [Plyushchan's nature]. Voronezh, Pabl. Nauchnaya kniga: 243-253.

7. Nedosekin V.Yu. 2016. Klass mlekopitayushchie - Mammalia [Class mammals - Mammalia]. In: Pozvonochnye zapovednika «Galich'ya gora» [Vertebrates of the Galichya Gora reserve]. Voronezh, Voronezh State University Publishing House: 144-165.

8. Pivanova S.V., Shubina Yu.E. 2010a. Gorodskoe kladbishche kak mesto sokhraneniya populyatsii krapchatogo suslika [City cemetery as a preservation site for the speckled ground squirrel population]. In: Vidovye populyatsii i soobshchestva $\mathrm{v}$ antropogenno transformirovannykh landshaftakh: sostoyanie i metody ego diagnostiki [Species populations and communities in anthropogenically transformed landscapes: state and methods of its diagnostics]. Materials of the XI Intern. scientific and practical ecology. conf. Belgorod, Pabl. Politerra: 177-178.

9. Pivanova S.V., Shubina Yu.E. 2010б. Razmnozhenie krapchatogo suslika v prigorodnoy zone goroda Lipetska [Reproduction of a speckled ground squirrel in the suburban area of the city of Lipetsk]. In: Pervye Mezhdunarodnye Bekkerovskie chteniya (27-29 maya 2010 g.) [First International Becker Readings (May 27-29, 2010)]. Ch. 1. Volgograd: 495-496.

10. Pivanova S.V., Shubina Yu.E. 2010в. Sostoyanie populyatsii krapchatogo suslika v prirodnoantropogennom landshafte gorodskogo kladbishcha i ego okrestnostey [Condition of the speckled ground squirrel population in the natural-anthropogenic landscape of the city cemetery and its environs]. In: Problemy izucheniya i vosstanovleniya landshaftov lesostepnoy zony [Problems of study and restoration of landscapes of the forest-steppe zone]. Collection of scientific articles. Tula: 268-270.

12. Proyavka S.V., Shubina Yu.E., Savinetskaya L.E., Shekarova O.N. 2017. Morphological characteristics of the speckled ground squirrel Spermophilus suslicus of the central part of European Russia. University proceedings. Volga region. Natural sciences, 2 (18): 3-10 (in Russian).

13. Sapelnikov S.F. 2019. Pochemu ne poluchilos' sozdat' novuyu koloniyu krapchatogo suslika (Spermophilus suslicus) [Why it was not possible to create a new colony of speckled ground squirrel (Spermophilus suslicus)]. In: Mlekopitayushchie Rossii: faunistika i voprosy teriogeografii [Mammals of Russia: faunistics and questions of theriogeography]. Conference materials (Rostov-on-Don, April 17-19, 2019), Moscow, KMK Scientific Press: 247-250. 
14. Sapelnikov S.F., Sapelnikova I.I. 2020. Rezul'taty reakklimatizatsii krapchatogo suslika na pastbishche i vozmozhnye perspektivy sokhraneniya vida [Results of re-acclimatization of speckled ground squirrel in pasture and possible prospects for species conservation]. In: Prostranstvennovremennye aspekty funktsionirovaniya biosistem [Spatio-temporal aspects of the functioning of biosystems]. A collection of materials of the XVI International Scientific Ecological Conference dedicated to the memory of Alexander Vladimirovich Prisniy (Belgorod, November 24-26, 2020). Belgorod, Publishing House "BelGU" NRU "BelGU": 112-117.

15. Sapelnikov S.F., Sapelnikova I.I. 2020a. Experience of reintroduction of Spermophilus suslicus Güld. in the Nature Park "Oleniy". In: Problems of Zoocultures and Ecology. Vol. 4. Moscow, GAU Moscow Zoo, EARAZA: 207-216 (in Russian).

16. Sapelnikov S.F., Sapelnikova I.I. 2021. Retrospective Analysis of Condition of Populations of Spermophilus suslicus Güldenstädt, 1770 in Central Black Earth Region and in Adjacent Territories and Possible Ways of Preserving the Species. Field Biologist Journal, 3 (2): 167-212. DOI: 10.52575/26583453-2021-3-2-167-212 (in Russian).

17. Sapelnikov S.F., Sokolov A.S., Lada G.A., Skryleva L.F. 2007. Pridorozhnaya koloniya krapchatogo suslika na avtotrasse Astrakhan' - Moskva v Tambovskoy oblasti [Roadside colony of speckled ground squirrel on the Astrakhan - Moscow highway in the Tambov region]. In: Teriofauna Rossii i sopredel'nykh territoriy [Theriofauna of Russia and adjacent territories] (VIII Congress of the Theriological Society). Materials of the international meeting. Moscow, KMK Scientific Press, 435 p.

18. Sapelnikov S.F., Sokolov A.S., Lada G.A., Skryleva L.F. 2007a. Ekologo-etologicheskie adaptatsii krapchatogo suslika Spermophilus suslicus k sovremennym usloviyam sredy obitaniya [Ecological and ethological adaptations of the speckled ground squirrel Spermophilus suslicus to modern environmental conditions]. In: Proceedings of the Voronezh State Reserve. Iss. 25. Voronezh: 279-285.

19. Sitnikova E.F. 2016. Krapchatyy suslik - Spermophilus suslicus Guldenstaedt, 1770 [Speckled ground squirrel - Spermophilus suslicus Guldenstaedt, 1770]. In: Red Book of the Bryansk region. $2^{\text {nd }}$ edition. Bryansk, RIO BSU: 373.

20. Zagorodnyuk I., Glowacinski Z., Gondek A. 2008. Spermophilus suslicus. The IUCN Red List of Threatened Species 2008: e.T20492A9208074. http:dx.doi.org10.2305IUCN.UK.2008. RLTS.T20492A9208074.en.

\section{ИНФОРМАЦИЯ ОБ АВТОРАХ}

Сапельников Сергей Фёдорович, зоолог Ломовского природного ландшафтного парка, Воронежская область, Россия

Сапельникова Инна Игоревна, старший научный сотрудник Воронежского государственного природного биосферного заповедника имени В.М. Пескова, г. Воронеж, Россия

\section{INFORMATION ABOUT THE AUTHORS}

Sergey F. Sapelnikov, Zoologist of Lomovskoy Natural Landscape Park, Voronezh Region, Russia

Inna I. Sapelnikova, Senior Researcher of Peskova Voronezh State Natural Biosphere Reserve Voronezh, Russia 